\title{
Dewey's Ethical Justification for Public Deliberation Democracy
}

\author{
John Shook
}

\section{ABSTRACT}

Interpretations of John Dewey's political theory grasp his respect for public deliberation, but typically overlook his ethical justification for democracy. Dewey gave two primary reasons why democracy is superior to other forms of government. First, a public educated in the tools of social intelligence can be more effective at managing their social conflicts. Second, all people have an ethical right to become as valuable to their communities as they can become. Dewey judged that only democracy ensures each person's ethical right to participate in social deliberation for the entire community's benefit. Dewey's model of social deliberation, "public deliberation polyarchy," applies a kind of "logic" for collective action, a process effective because of its ethical foundations.

John Dewey developed sophisticated theories for a liberal civil society and a deliberative democracy. These theories have recently enjoyed renewed attention, discussion, and practical application. ${ }^{1}$ However, no consensus on Dewey's primary theoretical strategies has yet emerged. ${ }^{2}$ What precisely was Dewey's justification for democracy and its superiority over other ways of life and forms of government? This essay explains how Dewey attempted to formulate a philosophical justification for democracy on ethical grounds, rather than just epistemic or satisfactionmaximization grounds alone. Provided with a solid ethical foundation, progressive and participatory democracy could become a practical, achievable, and highly rewarding endeavor for citizens. This paper offers a detailed exploration of Dewey's attempted justifications for his democratic theory, which have eluded almost all political theorists, and until this essay have not been carefully analyzed. Criticisms of his political theory and its ethical foundations, practical inadequacies, and conceptual confusions are deferred for separate treatment. Deferred as well are comparisons between Dewey's position, classical liberalism, recent cosmopolitanism, and other political theories.

Like many great political philosophers before him, Dewey held that the proper function of politics is to manage social conflict for the benefit of all involved. This view of the proper function of politics alone, while concerned for the general good, does not rise to the ethical level expected in Dewey's political theory. Managed democracies, aristocracies, and the like, composed by those who possess better claim 


\section{JOHN SHOOK}

to know what is best for all, or merely those who exercise superior power that luckily benefits the whole, cannot receive approval from Dewey's ethical politics. Dewey did not justify democracy solely on the utility of social intelligence, and therefore his political theory cannot be criticized for overlooking how expert intelligence can sometimes outperform social intelligence. Dewey gave two primary reasons why democracy is superior to aristocracy or any other form of government. First, a people educated in the tools of social intelligence can be more effective at managing their social conflicts than any aristocracy of expertise. Second, all persons have a moral right to become as valuable to their communities as they can become. When combined, these two reasons for democracy's superiority result in Dewey's conclusion that only full participatory democracy can ensure each person's moral right to participate in social deliberation for the entire community's benefit.

The particular type of participatory democracy designed by Dewey is what is here termed "public deliberation polyarchy." In public deliberation polyarchy, citizens motivated by common concerns organize into publics for political activism, and compete for the general public's sympathy and the government's attention. On Dewey's theory, voting is but one of many important activities that citizens can do to exercise their political power, and therefore pessimistic calculations about either the effectiveness or rationality of voting are only marginally relevant to judging Dewey's model of democracy. Dewey's model of social deliberation, as will be explained, applies a radically different type of "logic" for collective action. What makes this logic of social deliberation effective for achieving democracy's aims, according to Dewey, is a solidly ethical foundation. Democracy essentially is a practical tool for important moral aims.

Dewey's political philosophy is explained by successively considering seven distinct views about his justification of democracy. We first look at some inadequate views, and in the course of demonstrating their failure to correctly interpret Dewey, we are led to more adequate approaches. The first three inadequate views to be discussed are here labeled the American Tradition Justification, the Rights Justification, and the Freedom Justification. After hearing what Dewey has to say about tradition, rights, and freedom, we then proceed to consider three better theories about how Dewey attempted to justify democracy, here called the Epistemic Justification, the Individualism Justification, and the Ethical Justification.

The Epistemic Justification is the interpretation of Dewey most widely adopted by knowledgeable scholars, and for good reason: it adequately captures Dewey's concerns for rights, freedoms, and social intelligence. However, it is unfortunate that too much of Dewey scholarship has been stalled at this stage of interpretation, because the Ethical Justification view is a far better interpretation of Dewey's justification of democracy. Going one final step further, key aspects of Dewey's ethical theory, along with provocative writings of his later period, reveal that Dewey ultimately proposed the Moral Community Justification for progressive and participatory democracy. 
The Moral Community was, according to Dewey, both the practical pathway to democracy's fulfillment and the philosophical justification for democracy's superiority.

\section{The American Tradition Justification}

Dewey believed that confidence should be restored in traditional modes of democracy in America, such as the "town hall meeting."

According to this simplistic notion of Dewey's fondness for democracy, he called for America to preserve its traditions of small town and rural agrarian democracy during a time of accelerating urbanization and industrialization. The American Tradition Justification is a severe distortion of Dewey, because (1) nowhere in Dewey's writings does he use small town democracy as a positive inspiration for modern political theory; and (2) Dewey never thought that specific forms of political machinery were sacred or intrinsically better for all times and conditions.

Dewey's political theory does tightly link "community" and "democracy" as mutually supportive structures. Dewey often sought ways to strengthen the social bonds of communities in order to build a workable democratic politics, which in turn fosters the kinds of liberties needed for the growth of new communities. However, it would be a mistake to assume that Dewey's reference to "community" is a sign only pointing backwards to tradition. Critics have perhaps been misled by Dewey's suggestion (in The Public and Its Problems) that small town life provides an example of a democratic community. ${ }^{3}$ Dewey could not fail to acknowledge a prominent example from the historical origins of democratic community in America. However, after this passage he recounts the emergence of large cities, powerful states, and a strong national government. Noting that this momentum could not be reversed, and the founders' image of America is hopelessly inadequate today, Dewey declares that "The community pattern is more complicated, but is not destroyed." Although small town life can be an example of a genuine community, Dewey did not mean to say that it should be the only or even best form of community life. In The Public and Its Problems Dewey explores ways to grow communities appropriate to urban civic life, and offers a vision of a genuinely moral community adequate for large populations, the Great Community.

By taking a historical perspective on democracy's evolution, Dewey never supposed that some specific form of political machinery could be justified for all times and places. Town hall democracy could not be exalted as approaching perfection; indeed, specific democratic institutions must not be confused with the ideal of democracy itself. He wrote, "There is no sanctity in universal suffrage, frequent elections, majority rule, congressional and cabinet government." $\mathrm{By}$ sharply distinguishing the "democratic idea" from any concrete democratic institution, Dewey refused to define democracy primarily in terms of some set of political practices. 
This distinction provides for Dewey's pragmatic ground from which he can criticize actual institutions, according to whether they serve current needs of advancing democracy. However, what is Dewey's "democratic idea"? Dewey does have a sophisticated idea of democracy, and it has a great deal to do with the rights and freedoms so important for democracy.

\section{THE Rights JustifiCATION}

Dewey believed that democracy is the best form of government because it is grounded on basic rights for citizens, rights that Dewey consistently defended.

Dewey was a staunch and vocal advocate for a wide variety of crucial political and civil rights. He was a founding member of the NAACP and marched for women's suffrage. No public intellectual of his era was a more vigorous advocate of the rights of equal protection, free speech, voluntary association, due process, and political activism. However, the Rights Justification wrongly depicts Dewey as a political theorist who supposes that some basic rights can be identified and justified independently from broader social and political contexts. For Dewey, the opposite is the case: the existence of rights are dependent on broader social and political contexts.

Dewey continually cast scorn upon any notion, however central to past liberal reforms, that human nature could help justify the existence of "natural" rights and produce any type of democracy: "We cannot continue the idea that human nature when left to itself, when freed from external arbitrary restrictions, will tend to the production of democratic institutions that work successfully." Dewey did not doubt that an evolutionarily robust set of distinctive human instincts and traits characterize the species and permit its sociality. However, such social elements are evidently compatible with a very wide array of social structures and governments proven viable across human history.

The Rights Justification distorts Dewey because (1) Dewey argued that there really are no basic rights in the sense of "absolute," "permanent," or "natural" rights; (2) Dewey always talked of rights as contextual, provisional, and hypothetical tools for dealing with the needs of social organization; and (3) Dewey believed that rights are social artifacts, created by society's bestowal of specialized responsibilities in the course of advancing the common good.

The social context of rights was a consistent theme in Dewey's political theory:

The social factor in rights is made explicit in the demand that the power in question be exercised in certain ways. A right is never a claim to a wholesale, indefinite activity, but to a defined activity; to one carried on, that is, under certain conditions. This limitation constitutes the obligatory phases of every right. The individual is free; yes, that is his right. But he is free to act only according to certain regular and established conditions.... Absolute rights, if 
we mean by absolute those not relative to any social order and hence exempt from any social restriction, there are none. But rights correspond even more intrinsically to obligations. The right is itself a social outcome: it is the individual's in so far as he is himself a social member not merely physically, but in his habits of thought and feeling. He is under obligation to use his rights in social ways. ${ }^{7}$

Dewey's progressive liberalism does not accept the explanation that the political realm must artificially establish rights, as rights cannot be found in individuals. While rights are not grounded on people as individuals, there is a social sphere of duties and rights that exists prior to, and relatively independent from, any political rights. Government is not instituted to protect individual rights, but rather to advance social welfare, and it undertakes this task by adding a layer of political duties and rights to those already functioning for the social sphere. Not only are there no presociety property rights or voting rights, all civil rights are likewise outgrowths from social progress: "It must be realized that civil rights, liberty of speech, assembly, publication, are not merely individual rights, but are essential to the welfare, the healthy growth, of society." Government should respect individuals' rights (for example, judges should start from the existence of current rights), but the question of which rights people have must be decided by public deliberation about the social good. Similarly, the search for social progress by various societies will never converge on a single way of life, so there is no reasonable hope for empirically discovering a single best system of rights or of justice. ${ }^{9}$

Dewey does have many things to say about the concept of rights generally, which can only be summarized here. Negative rights, the guaranteed freedoms from public intervention and control, are indeed valuable according to Dewey, but other goods are also important and perhaps sometimes more important. For example, the category of positive rights, those rights which require public aid to provide some needed goods to people who cannot obtain them by themselves, will be valued much more highly by someone in a situation where negative rights alone are leaving them out of work, homeless, and starving. Defenders of negative rights (such as libertarians) complain that any positive right must violate some negative right, but always prioritizing negative rights is a questionable (and unrealistic) presumption. Dewey's political theory instead finds that it is reasonable for real people in their actual social situations to deliberate over the relative prioritization of negative and positive rights, and to make pragmatic choices depending on their circumstances. Rather than obey some previous generation's list of preferred rights, Dewey expected the people to periodically reconsider the value and efficacy of their rights, and to use all available methods of nonviolent social change from voting and petitioning to marching in order to achieve the modification or supplementation of those rights (Dewey himself marched in New York City for women's suffrage, as biographers recount). 
Furthermore, Dewey could not regard negative rights as sufficient for democracy, emphasizing that citizenship rights always carry responsibilities over and above correlate duties to avoid harming others. While Dewey did believe that democracy should deliberate about, and staunchly protect, some robust negative rights and some robust positive rights, Dewey's political theory also proposes a third category of rights. He did not attach a label to this category, so I suggest the label of empowerment rights. A simple example is my right to drive a car. This right cannot be easily categorized as a negative right or a positive right, since the government may interfere with the way I drive, and the government requires that I drive responsibly for the good of others as well as my own good. My right to drive a car is a right earned by learning how to drive safely and obey traffic laws. It is also a right with responsibilities attached, since my right can be taken away if I fail to drive safely and legally. Empowerment rights are rights that empower a person to pursue their own good in some specified way under the responsibility requirement that they simultaneously exercise that pursuit in a way consistent with the greater good. A license to practice medicine is another common example of an empowerment right. It may be the responsibility of the government to help people gain empowerment rights, if having those empowerment rights is a sufficiently crucial community good. These "community" empowerment rights would therefore be rights in which the government has the duty to empower a person for some capacity because that person can responsibly exercise that capacity for his or her own good and the community good.

Dewey regarded three kinds of rights as necessary for the proper functioning of democracy. Dewey's understanding of freedom is similarly sophisticated, as he also demands that freedoms be understood in their social context, and comprehended as more than just liberties.

\section{THE FREEDOM JustiFicATION}

Dewey believed that democracy's emphasis on human liberty provides a better opportunity for the people to enjoy freedoms: such as freedom of one's chosen way of life, or freedom of thought, or freedom to enjoy the growth of experience.

While freedoms in a thin sense exist prior to and independent of any political society, such freedoms have little significance or value. What people really want is never simply freedom in itself but rather real capacities: actual abilities to accomplish chosen goals. Because most of our capacities are developed and maintained by cooperation and instruction from others, capacities are typically social in nature. Like rights, the freedoms worth valuing exist only in a social context. Dewey writes, "Liberty is that secure release and fulfillment of personal potentialities which take place only in rich and manifold association with others: the power to be an 
individualized self making a distinctive contribution and enjoying in its own way the fruits of association. Equality denotes the unhampered share which each individual member of the community has in the consequences of associated action." ${ }^{10}$

The freedom justification falls short of capturing Dewey's approach to politics because (1) Dewey considered negative freedoms (placing restrictions on others from obstructing one's own efforts to achieve aims) to be inferior to positive freedoms (one's real capacities to actually achieve intelligently considered aims); (2) Dewey never approved of such freedoms for their own sake, but always talked about freedoms in relation to the ultimate freedom to be intelligent; and (3) Dewey wanted freedoms to empower individuals for positively enhancing the social good.

Liberty is indeed a supreme value of life. Yet its social nature, evident in both liberty's causes and consequences, supplies both its justification and its limits. Like his position on civil rights, Dewey was explicit about the social nature and justification of civil liberties:

The only hope for liberalism is to surrender, in theory and practice, the doctrine that liberty is a full-fledged ready-made possession of individuals independent of social institutions and arrangements, and to realize that social control, especially of economic forces, is necessary in order to render secure the liberties of the individual, including civil liberties. ${ }^{11}$

Liberties must be coordinated, not merely with each other, but more importantly with the pursuit of the social good of all:

Unless freedom of individual action has intelligence and informed conviction back of it, its manifestation is almost sure to result in confusion and disorder. The democratic idea of freedom is not the right of each individual to do as he pleases, even if it be qualified by adding 'provided he does not interfere with the same freedom on the part of others.' While the idea is not always, not often enough, expressed in words, the basic freedom is that of freedom of mind and of whatever degree of freedom of action and experience is necessary to produce freedom of intelligence. The modes of freedom guaranteed in the Bill of Rights are all of this nature: Freedom of belief and conscience, of expression of opinion, of assembly for discussion and conference, of the press as an organ of communication. They are guaranteed because without them individuals are not free to develop and society is deprived of what they might contribute. ${ }^{12}$

Freedoms must be harmonized because a person's free activities may interfere with, or completely eliminate, other persons' opportunities for their own free activities. The attainment of any sort of balancing of freedoms, especially such balances as may improve society, requires thoughtful adjustment of limitations on peoples' freedoms. There could not possibly be any a priori method of setting such limits, since the modes of human action and types of social relations are innumerable and constantly growing, and the prioritization of those modes would have to be determined in ad- 
vance for all. An a priori method would therefore proceed only by artificially limiting modes of action and imposing a prioritization on the people. The alternative to totalitarianism is democracy: the people themselves thoughtfully adjusting their freedoms in light of their priorities. For Dewey, this is the genuine significance of liberty:

Liberty to think, inquire, discuss, is central in the whole group of rights which are secured in theory to individuals in a democratic social organization. It is central because the essence of the democratic principle is appeal to voluntary disposition instead of to force, to persuasion instead of coercion. Ultimate authority is to reside in the needs and aims of individuals as these are enlightened by a circulation of knowledge, which in turn is to be achieved by free communication, conference, discussion. ${ }^{13}$

Democracy is essentially the peaceful and thoughtful effort to justly balance freedoms among persons, and therefore is a type of nonviolent conflict resolution. The proper justification of democracy, for Dewey, must be more about ethical social participation than about personal liberty.

\section{The Epistemic Justification}

Dewey proposed that democracy's mode of public deliberation allows participants to learn how to peacefully resolve their social problems in the political sphere.

Dewey argued that citizenship in a democracy requires a small number of essential community empowerment rights that revolve around key civic virtues which promote tolerance for diversity, capacity for cooperation, and effectiveness in group deliberation. Dewey's theory of progressive democracy is a vision of the intelligent methods of public deliberation that permit genuine "self-rule" by the body of citizens. Civic education in Dewey's sense, as developing capacities for the problem solving of public conflict resolution, is essential to the proper functioning of a democracy. ${ }^{14}$

The epistemic justification accounts for Dewey's abiding concern for not merely the education and intelligence of the masses, but specifically for people's capacity to participate in group problem solving about social conflicts. Dewey labels this capacity as "organized intelligence" or "social intelligence":

Of course, there are conflicting interests; otherwise there would be no social problems. The problem under discussion is precisely how conflicting claims are to be settled in the interest of the widest possible contribution to the interests of all-or at least of the great majority. The method of democracy-insofar as it is that of organized intelligence-is to bring these conflicts out into the open where their special claims can be seen and appraised, where they can be discussed and judged in the light of more inclusive interests than are represented by either of them separately. ... What generates violent strife is 
failure to bring the conflict into the light of intelligence where the conflicting interests can be adjudicated in behalf of the interest of the great majority. ${ }^{15}$

Dewey found in social intelligence the resources to reply to the oft-made accusation that decisions by majority rule are only rarely and coincidentally the wisest course. Dewey never thought that participatory democracies always produce the best results, especially according to current standards of justice or public welfare. All the same, our current standards are largely the result of past democratic deliberations and emerging majority decisions, and not from expert punditry or dictatorial fiat.

For Dewey, public conflict resolution is typically improved as more citizens are involved in its deliberations. Where fears are justified that some given number of citizens are inadequate to a novel problem, such as matters of international or even global concern, expanding the number of citizens involved is preferable to the alternative of handing over decisions of such vast magnitude to self-proclaimed experts. Comparisons with cosmopolitanism are beyond the scope of this article (readers may have noticed considerable overlap with cosmopolitanism already), yet it deserves mention that no one should assume that Dewey designed his theory of democracy solely for domestic politics sequestered within countries. Rather, Dewey insisted that democracy flourishes where all those affected can participate in deliberations regardless of recognized citizenship (in other words, citizenship is a by-product of effective participation, not the other way around). Yet mass deliberations can be slow and unsteady. Aristocracies always pride themselves on their speedy conclusions, as far fewer people are involved, and aristocracies also conveniently self-select their members by pre-established criteria of mutual admiration and agreement. However, these are not conditions favorable to the sort of robust inquiry and deliberation that Dewey has in mind. Larger majorities have greater epistemic validity than smaller majorities or tiny minorities, where general social welfare is concerned:

The ballot is, as often said, a substitute for bullets. But what is more significant is that counting of heads compels prior recourse to methods of discussion, consultation and persuasion, while the essence of appeal to force is to cut short resort to such methods. Majority rule, just as majority rule, is as foolish as its critics charge it with being. But it never is merely majority rule. As a practical politician, Samuel J. Tilden, said a long time ago: 'The means by which a majority comes to be a majority is the more important thing': antecedent debates, modification of views to meet the opinions of minorities, the relative satisfaction given the latter by the fact that it has had a chance and that next time it may be successful in becoming a majority. ${ }^{16}$

Although Dewey calls for enhancing the social conditions permitting democracy to be more intelligent, many Dewey commentators have complained that he offers no pragmatic theory of the actual "machinery" of democratic deliberation. Perhaps they get distracted by Dewey's own clumsy political activities and forget 


\section{JoHN SHOOK}

to look for political theory in his writings. It is at least clear that Dewey did not intend to hand over the government to expert intellectual elites, unlike critics such as his contemporary, Walter Lippmann. Lippmann derides participatory democracy, describing ordinary citizens as too ignorant, apathetic, and selfish to be capable of helping to govern for the public good. ${ }^{17}$ Dewey's political theory answers each of these charges made against citizens.

The method of intelligence, according to Dewey, is first and foremost the logical process of problem solving. Confidence in democracy is therefore confidence in the intelligence of citizens to resolve social conflicts:

Democracy is a way of personal life controlled not merely by faith in human nature in general but by faith in the capacity of human beings for intelligent judgment and action if proper conditions are furnished. . . For what is the faith of democracy in the role of consultation, of conference, of persuasion, of discussion, in formation of public opinion, which in the long run is selfcorrective, except faith in the capacity of the intelligence of the common man to respond with commonsense to the free play of facts and ideas which are secured by effective guarantees of free inquiry, free assembly and free communication? ${ }^{18}$

Commentators have not yet noticed something highly interesting about Dewey's theory of problem solving and his theory of "publics": the stages of each process match step for step. This is not a coincidence, but a confirmation that Dewey had concrete proposals for how democracy can pragmatically work in America.

First, the stages of scientific inquiry, according to Dewey's Human Nature and Conduct and Logic: The Theory of Inquiry. (1) A problem with habitual conduct arises. (2) The prevailing natural conditions are surveyed to discover which features of the situation are relevant to the problem. (3) Hypotheses are formulated to suggest a course of action to resolve the problem. (4) One hypothesis is selected for experiment and its consequences are observed. (5) The problem is either solved, or the process returns to stage two.

Second, the stages of public inquiry, according to Dewey's The Public and Its Problems. (1) A number of people become collectively aware that they suffer from the same social problem, and if they have sufficient interest and energy to work together on this problem, they form a "public." (2) This new public, perhaps with the aid of social scientists, survey social conditions to identify which are probably responsible. (3) Hypotheses are formulated by this public, perhaps in alliance with other publics, to suggest what modifications to social structures and/or norms may alleviate the social problem. (4) If persuaded, a majority of the Public (the whole body of citizens) agrees to experiment with one of the proposed social modifications, pressures branches of local, state, and/or federal government to implement the modifications, and the experiment's consequences are observed. (5) The social problem is either alleviated sufficiently so that the public loses energy/members, or the process returns to stage two. 
Both processes of inquiry presuppose some degree of community goodwill and respect for all participants, even as these processes encourage fierce competition between subgroup aims. This is the essence of democratic polyarchy: Political power is distributed over many energetic publics competing for community and government attention to their aims (such as political parties, religious organizations, businesses, unions, political action committees, trade groups, grassroots community groups, charities, etc.) Furthermore, both processes of inquiry assume the existence of routes of communication for sustaining both the community over the long run and for supporting the emergence of new publics to compete with each other over the short run.

Robert Dahl proposed the term "polyarchy" as a label for a society with political structures and norms that protected fair and effective competition among politically active citizens and their organized groups. Dewey's theory of political democracy could be labeled "public deliberation polyarchy." ${ }^{19}$ Dewey does agree with Dahl that a genuine democracy will facilitate the uprising of activist and protest groups, what Dewey labeled as publics, by providing conditions for easy communication, free association, and honest media information. Furthermore, a genuine democracy will provide the sort of civic education that (1) fosters mutual respect and appreciation for all members of society, and (2) teaches the skills of collective problem solving. If a democracy can meet these minimal requirements, then those publics that do arise can frequently get a fair hearing before the entire community-the Public. Such a democratic society would also be more resistant to authoritarian temptations, which critics of liberal democracy fear would be irresistible to an undereducated and apathetic populace.

Dewey does not assume that those benefiting the most from the existing social structure will lead the way to progress; indeed, his theory of democratic publics assumes that the opposite will remain the case. This is why he is so skeptical towards elitist theories of democracy (like Lippmann's) that suppose that a class of comfortable intellectuals will work for the benefit of the entire society. Those benefiting least have the most problems to complain about, and have the most determination to cause change, all other things being equal. Of course, things are rarely so equalsocial structure and ideology obstruct the recognition of severe social problems even by the sufferers. Still, Dewey places the primary responsibility for attempting change upon those who suffer the problems. This seems profoundly unjust in spirit, but Dewey feared the alternative even more: placing the primary responsibility for detecting and solving social ills upon the shoulders of those who do not feel that suffering. Those who suffer must organize, protest, and propose change. This is Dewey's naturalistic theory of cultural evolution: cultural evolution is not pulled by a supreme beneficent power but is instead pushed by the experimental testing of innumerable small and gradual modifications.

Because politics proceeds incrementally, Dewey's citizens need not each be the all-around political expert that Lippmann supposes would be required to make par- 


\section{JOHN SHOOK}

ticipatory democracy work. Against Lippmann's charge of citizen ignorance, Dewey answers that organized publics can be very intelligent, especially when many intellectuals work for them. Against the charge of apathy, Dewey answers that members of publics can be highly motivated, especially when they see evidence that their time, energy, and money is making a difference. Against the charge of selfishness, Dewey expects that citizens who demand that their suffering be recognized also be capable of caring about the suffering of others (here again civic education is crucial), so that publics and the citizens that make up the Public can view the democratic process as a potential win-win situation and not as a zero-sum game.

As demonstrated by this brief sketch of Dewey's theory of public deliberation polyarchy, he was concerned to offer multiple ways of seeing how democratic deliberation, as opposed to the deliberations of elites, could improve the resolution of social conflicts. For many commentators, this ability of democracy constitutes Dewey's best justification for democracy: democracy is the more practical tool for social conflict resolution for the social good. After all, a pragmatist should try to justify the social institution of democracy by its practicality.

Nevertheless, there are four major difficulties with taking the epistemic justification to be Dewey's ultimate justification for democracy. (1) Dewey preferred to speak primarily of democracy as "a way of life" for all members of society and only secondarily as a mode of political activity for energized citizens. (2) Dewey regarded universal adult suffrage as essential to genuine democracy, rejecting the notion that only sufficiently capable deliberators should be politically active. (3) Dewey was always concerned that democracy be designed to idealistically search for the welfare of all members of society, and not for only what actual adult political participants view as good for themselves individually or collectively. (4) Democracy considered merely as a practical method for resolving social conflicts supplies but a vague criterion for actually gauging social progress.

Dewey's primary justification of democracy is not its practicality for experimenting with solutions to social conflicts (though he often enough pointed out this virtue). Nor does Dewey justify participatory democracy by claiming that democracies even frequently achieve improved welfare for all society (although that frequency is greater in the long run than any aristocracy or monarchy). Rather, like all other kinds of genuine inquiry, it is the committed search for the general good, and not its guaranteed achievement by some transcendent criterion, that characterizes democracy.

Any advocate like Dewey for participatory democracy is targeted by the criticism that "the general good" is hardly a reasonable goal, either because the notion is incoherent, or simply impractical. However, Dewey's theory of democracy does not require achieving at one stroke the greatest welfare for all (there can't be a formula for determining that), but it only demands our best efforts at incrementally moving towards that ideal goal through social change-and there is no lack of evidence 
that democratic societies have accomplished such movements. Knowing that one's society has shown fidelity to an ideal ethical goal by eliminating a social problem or conflict is quite possible, even if no one can precisely say what a society entirely fulfilling that ethical goal would look like.

Ethical ideals are too distant and vague for serving as immediate measures of social welfare, yet they still have their proper function for guiding democracies. One wishes for more specific and detailed guidance when democratic progress is unsteady, but there is no precise criterion of "the good" or "the right" to resort to when participatory democracies stumble, stalemate, or stagnate. Complaining that democracies occasionally require supplementation from other sources (pure reason? God?) is far more unrealistic than the hopes for democracy. Besides, democracy at its best, for Dewey, is a gradually self-corrective mode of social inquiry, akin to science. Where do critics of democracy suppose absolute rights and values will arrive from? One might as well complain that scientific inquiry is inefficient compared to simply knowing nature transempirically. Science rightly replies that only more scientific inquiry can supply needed clues for improving scientific method. Democracy is inefficient, to be sure, but democracy is humanity's own social technology only to be gradually improved by more democracy by the people. Democracy's current foundations consist of our highest ethical ideals and already achieved political structures, and not any sort of transcendent or a priori principles.

Ultimately, Dewey demanded that all of society have equal opportunity to participate in deliberative politics and enjoy the benefits of social progress. His debate with Lippmann demonstrates this appeal. Lippmann's main argument for elitist democracy was precisely that it was the most practical: an intellectual aristocracy could, arguably, best resolve social conflicts for the social good. Dewey rejected such an aristocracy, not by any empirical evidence of participatory democracy's actual effectiveness (although he believed that adequate evidence was obvious), but because Dewey was more interested in defending the essence of democracy by concentrating on the ethical treatment of the actual people that compose society:

For democracy signifies, on one side, that every individual is to share in the duties and rights belonging to control of social affairs, and, on the other side, that social arrangements are to eliminate those external arrangements of status, birth, wealth, sex, etc., which restrict the opportunity of each individual for full development of himself. On the individual side, it takes as the criterion of social organization and of law and government release of the potentialities of individuals. On the social side, it demands cooperation in place of coercion, voluntary sharing in a process of mutual give and take, instead of authority imposed from above. As an ideal of social life in its political phase it is much wider than any form of government, although it includes government in its scope. As an ideal, it expresses the need for progress beyond anything yet attained; for nowhere in the world are there institutions which in fact operate 


\section{JOHN SHOOK}

equally to secure the full development of each individual, and assure to all individuals a share in both the values they contribute and those they receive. ${ }^{20}$

Dewey's basic political orientation aligns him with much of the political tradition of republicanism (though he rarely discussed it directly in his writings, for it wasn't as common a political term then). Republicanism stresses that citizenship is not defined by the citizen's relationship to a government, but rather by the citizen's relationship to fellow citizens. That relationship must be one of political equality and nondomination among peers, so that the body of citizens may freely exercise the capacity for self-ruling power. ${ }^{21} \mathrm{~A}$ republican conception of "equal opportunity" accordingly finds that everyone should have an equal opportunity to become empowered for meaningful political participation. Such opportunity must be provided by the public's attainment of those community empowerment rights, through civic education, needed in the political sphere. If Dewey is related to republicanism, only a very expansive republicanism could serve. Narrow versions of republicanism requiring ethnic homogeneity, nationalistic heritage, and the like cannot find any home in Dewey's political theory.

This broad political equality, with the proviso that Dewey demanded universal adult suffrage, is Dewey's primary understanding of equal opportunity (without denying that there are other needed forms of equal opportunity in the economic or social spheres). Equality of political empowerment and participation comes in many forms; there are numerous capacities for political involvement besides public conflict resolution that will not be discussed here. However, given that democracies will contain many social groups pursuing diverse values and hence causing many social conflicts, stable and peaceful democracies should pursue public conflict resolution. Civic education for all, according to Dewey, is the instrument making the social intelligence of public deliberation possible in a republican democracy. In this sense, Dewey freely applied the label of "liberalism" to his political theory, writing that "Liberalism has to assume the responsibility for making it clear that intelligence is a social asset and is clothed with a function as public as is its origin, in the concrete, in social cooperation." ${ }^{22}$ Dewey's political theory is thus a version of that fruitful convergence of republicanism and liberal democracy found in many modern thinkers. Dewey's public deliberation polyarchy rests on the grounding principle that the dignity and self-fulfillment of every person should be of community concern.

\section{THE INDIVIDUALISM JUSTIFICATION}

Dewey believed that democracy's emphasis on individuals is the essence of liberalism, which always seeks to expand opportunities for all individuals.

According to the individualism justification, democracy is justified by its foundational respect for the value and importance of all persons. Dewey repeatedly used 
the concept of equal opportunity to indicate how every person's capacities for successful living must have social standing and importance. He declared, "The democratic faith in human equality is belief that every human being, independent of the quantity or range of his personal endowment, has the right to equal opportunity with every other person for development of whatever gifts he has." ${ }^{23}$ Dewey explicitly connected the practical success of democracy with its promotion of equal opportunity for all. He argued that the effectiveness of social problem solving is diminished if there are some members of society incapacitated for political participation. His theory of public deliberation polyarchy places the burden of noticing social problems and energizing publics upon the common people. Furthermore, there is no good sense in artificially limiting the portion of society fit for public deliberation: the more minds involved, the better, has been the modern scientific motto. Ensuring equal opportunity for civic life makes double sense in a democracy: democracy is supposed to be for the people, and also by the people, to borrow Lincoln's phrase:

As far as I can see, the hope of maintaining democracy lies in using the enormous resources that science has put in our hands to inaugurate not merely an age of material plenty and material security, but also of cultural equality of opportunity - the opportunity of every individual to develop to his full capacity. ${ }^{24}$

This individualistic foundation for democracy must not be confused with that "rugged" individualism that from time to time has dominated the myths of the American dream. The notion of rugged individualism also appealed to the ideal of "equal opportunity" while ignoring the balancing ideal of social responsibility for enabling such opportunity. Consistent with his refusal to prioritize negative rights, Dewey sought social harmony and justice elsewhere, as noted above in the discussion of positive rights and empowerment rights. The individualism justification captures Dewey's demand that society take responsibility for people's capacities. For example, Dewey argued that education should be life-long; retraining of adults for new jobs must be state-supported. Dewey's preference for socialism, requiring both legislative restraint upon business and ample state funding for empowering individuals, is accounted for with the individualism justification.

There remain two major problems for the individualism justification. (1) Given Dewey's objections to excessive individualism, what sort of individuality does Dewey want? (2) How does Dewey explain why all human beings should enjoy equal opportunities? Dewey's writings supply his clear answers to these valid questions, by moving to the realm of morality.

\section{The Ethical Justification}

Dewey believed that democracy's equal concern for the welfare of all persons supplies the ultimate ethical ground for the superiority of democracy. 
According to this justification, a firm commitment to an ethical principle of moral equality for all people grounds Dewey's variety of individualism. This principle of human moral equality (elaborated in the next section on the Moral Community) is universal in the sense that Dewey intended to include all humanity regardless of cultural differences and regardless of whether democracy yet prevails in all societies. Dewey's conception of this "human equality" is not grounded on any physical or material equality, supposed or real: we are firmly in the ethical realm of how people should be treated.

Dewey's demand for the universal application of this principle of human moral equality should not be confused with any sort of ethical universalism or absolutism, which instead searches for timelessly and rationally valid moral truths that can never change. As a pragmatist, Dewey had no place in his philosophy for such quests. All the same, his democratic political theory is expressly grounded on a principled morality of human equality. Dewey discerned such a principle in the Founders' intentions:

With the founders of American democracy, the claims of democracy were inherently one with the demands of a just and equal morality.... What they asserted was that self-governing institutions are the means by which human nature can secure its fullest realization in the greatest number of persons... We have advanced far enough to say that democracy is a way of life. We have yet to realize that it is a way of personal life and one which provides a moral standard for personal conduct. ${ }^{25}$

Discovering the fuller import of Dewey's phrase above that "democracy is a way of life" must await the moral community justification (below), towards which the ethical justification leads. What is already apparent is Dewey's effort to bond together morality and politics in a way that modern liberalism has typically avoided. In the next selected passage, Dewey offers one of the most robust and detailed formulations of his ethical principle of equality for democracy:

From the ethical point of view, therefore, it is not too much to say that the democratic ideal poses, rather than solves, the great problem: How to harmonize the development of each individual with the maintenance of a social state in which the activities of one will contribute to the good of all the others. It expresses a postulate in the sense of a demand to be realized: That each individual shall have the opportunity for release, expression, fulfillment, of his distinctive capacities, and that the outcome shall further the establishment of a fund of shared values. Like every true ideal, it signifies something to be done rather than something already given, something ready-made. Because it is something to be accomplished by human planning and arrangement, it involves constant meeting and solving of problems - that is to say, the desired harmony never is brought about in a way which meets and forestalls all future developments. ${ }^{26}$ 
For Dewey's progressive liberalism, democratic individualism must evolve towards democratic socialism: the expansion of every individual's capacities and powers is precisely the process of social coordination requiring some political management. Dewey was hardly the first political theorist to identify the function of politics as managing the social coordination of everyone's proper development. This view of politics has resulted in theories across the centuries which defend autocracy, aristocracy, fascism, communism, as well as varieties of democracy. These theories almost always start from some concrete notion of what constitutes a person's proper development. Dewey's progressive liberalism is nearly unique because it offers no specific concept of what could constitute a person's proper development. Dewey's writings are replete with pleas for the development and empowerment of people's abilities. But nowhere can Dewey say anything specific about the best character traits or the finest virtues or the best way of life for a person in general. There is no specific human telos in Dewey's philosophy. Dewey self-consciously refuses to give any such specifics: Dewey has no idea what those things are. His ignorance is a key foundation to his theory of democracy. And Dewey would make us see that his ignorance should be our ignorance. No one could know what a human being ought to become.

We can still have some ideas about what a human being ought not to become. There should be moral and political constraints upon what a person should become, constraints that follow from the ethical principle that all people should have the equal opportunity to realize their potential. Political theories have typically remained focused on constraints, because that is the far easier problem to solve: given a conception of the human telos, and a notion of the social coordination required for groups to attain their telos together, the needed constraints on human behavior can be derived fairly easily. Dewey's political theory has no conception of human telos and only an understanding of many of the forms of social coordination tried so far. That's how Dewey derives his theory of democracy: the people themselves must take the responsibility for exploring their potentials and coordinating their common search using novel social organizations. Democracy is an endless experiment designed and conducted by the people themselves.

Dewey believed that democracy's equal concern for the welfare of all persons supplies the ultimate ethical ground for the superiority of democracy. Yet this ethical justification stage is not the final stage of understanding Dewey's political theory and his justification for his specific type of liberal democracy. Two crucial questions must be asked. (1) Even if the welfare of all ought to be of supreme concern, how is it possible to find such concern manifested in each person's experience of community life? (2) What would a democracy that actually approaches this ideal of moral equality actually look like? 


\section{The Moral Community Justification}

Dewey believed that democracy is the form of social and political organization that naturally fulfills the ethical criterion of the genuine community: that all people are committed to the principle of moral equality.

This at last is Dewey's ultimate justification for democracy. This justification does not rest on the principle that each person possesses supreme moral value. Although Dewey believed this principle to be true, he also viewed it as an inadequate abstraction. Taken too concretely, this principle can lead back to the excessive individualism behind the notions of absolute rights and liberties.

Although each person must have the opportunity for personal development, that development does not take place in a vacuum. The social context of personal development is fairly acknowledged by defenders of individual rights and personal autonomy, who well understand that firm constraints on everyone's conduct are required to prevent society from overwhelming the individual. The evident need for firm restraints facilitated the notion of political equality, while a conception of moral equality required longer germination. Democracy's early forms prioritized political equality to reinforce restraint, upon the peoples' conduct for each other and also upon the government's conduct towards the people. For classical eighteenth century liberalism, rights and autonomy were deemed sufficient foundations for democratic government. However, the responsibilities of each person were thereby conceived primarily as responsibilities to refrain from certain conduct (e.g., the prevalence of negative rights). Nineteenth century utilitarianism added the demand that citizens exercising their self-ruling power should also search for ways to increase the common good and overall happiness of the people. Unfortunately, the contradictions between simultaneously trying to protect individuals from society and trying to increase overall social welfare were inescapable and unsolvable. Liberalism and utilitarianism were headed for a collision precisely because they agreed on the centrality of the individual qua individual, making it difficult to justify personal sacrifice for the greater good. Compromise forms of political liberalism then proliferated across the landscape of twentieth century political theory as various combinations and relations of deontological and utilitarian principles suggested themselves.

Dewey proposed a radical way to transcend this impasse: each person should conceive of his or her own good as integrally connected with the welfare of all others. But why should people accept this conception? As an empirical question, whether one's good will be positively related to the social good may be statistically evaluated. Even if this positive correlation is valid for the vast majority of people in most sorts of societies, as Dewey believes, this empirical fact is not a sufficiently secure foundation for democracy. Rather, Dewey specifically proposed that a person should highly 
value the common good precisely because it is the common good and not merely because that person finds the common good to be also good for him or her individually.

Dewey realized that a severe obstacle to encouraging people to highly value the common good is the notion that the person qua individual is the supreme locus of moral and political value. That individualism obscures the realization of community. A community for Dewey is more than just a voluntary association of people cooperating for some common goal: additionally, the members of this social group all work to sustain this group because they value the fact that all are benefitting, and not merely because they are personally benefitting. In a genuine community, occasional sacrifice for others is easily accounted for; altruism is not mysterious or irrational. The community, defined in this way by Dewey, supplies the way of life vital to democracy:

Regarded as an idea, democracy is not an alternative to other principles of associated life. It is the idea of community life itself.... Wherever there is conjoint activity whose consequences are appreciated as good by all singular persons who take part in it, and where the realization of the good is such as to effect an energetic desire and effort to sustain it in being just because it is a good shared by all, there is in so far a community. The clear consciousness of a communal life, in all its implications, constitutes the idea of democracy. ${ }^{27}$

On Dewey's definition of community, it is not necessary for people to value others as highly as they value themselves; no radical egalitarianism lurks here. Obviously, communities will fall apart if too many people feel that excessive sacrifice is demanded of them. All the same, communities must be glued together by some powerful form of mutual regard and concern in order to function well and enjoy longevity. Dewey argued that the political principles of restraint formulated by classical liberalism cannot generate that degree of mutual regard and concern, since they proceed from an excessive regard for personal value.

What foundation for the community could simultaneously supply the justification for political restraint and also the motivation for a high degree of mutual regard and concern? Dewey offers an ethical foundation: the community's members are faithfully committed to the principle of moral equality. This commitment may be manifested in a wide variety of ways, too many to be enumerated. At minimum each person's commitment to moral equality is embodied in his or her moral experience of community life. In The Public and Its Problems Dewey envisions a genuinely moral community adequate for large populations: the Great Community. In the Great Community, everyone's moral experience of conducting all social relationships in the spirit of equality supplies the motivation that each citizens needs for peacefully resolving social conflicts:

Democracy as a way of life is controlled by personal faith in personal day-byday working together with others. Democracy is the belief that even when needs and ends or consequences are different for each individual, the habit of 
amicable cooperation - which may include, as in sport, rivalry and competition-is itself a priceless addition to life. To take as far as possible every conflict which arises-and they are bound to arise-out of the atmosphere and medium of force, of violence as a means of settlement into that of discussion and of intelligence is to treat those who disagree-even profoundly-with us as those from whom we may learn, and in so far, as friends. A genuinely democratic faith in peace is faith in the possibility of conducting disputes, controversies and conflicts as cooperative undertakings in which both parties learn by giving the other a chance to express itself, instead of having one party conquer by forceful suppression of the other. ${ }^{28}$

Dewey's conception of democracy as primarily a cultural way of life is the foundation for his justification of democracy as a political system. In the democratic way of life, people are already motivated to cooperate for group gain, and motivated to use nonviolent means to overcome obstacles to cooperation. Of course, many people also have motivation to cheat as free riders, harm the interests of others, or use violent means for gain. The sources of social conflict are many, and government can be a tool for managing social conflict. Democratic government ideally should be the formal arrangement of political power that most exemplifies the principles of the democratic way of life. These principles are expressed by the epistemic justification, the individualism justification, and the ethical justification. Each principle by itself incompletely and imperfectly treats an aspect of managing social conflict; when linked together, they blend into an ideal and practical justification for democracy. These three justifications jointly explain how the democratic ideal of equality reaches practical fulfillment in the democratic moral community. The sort of equality essential to democracy is neither natural equality, material equality, nor political equality; only moral equality is the essence of democracy. However, it must be stressed again this notion of moral equality needed by Dewey is of a peculiar sort, capable of making democracy practical.

Having no fixed, static conception of the moral good for humanity, Dewey can only point to the potentialities and opportunities which each person might explore and develop if social conditions are favorable. The moral equality that democracy promises is basically an equality of opportunity. This equality of opportunity is shallow and hollow if people's capacities are thought of as delimited beforehand; what is important about people is not their actual capacities at any given point in their lives, but rather their potential capacities that would be realized under future conditions:

Democracy is a way of life controlled by a working faith in the possibilities of human nature. Belief in the Common Man is a familiar article in the democratic creed. That belief is without basis and significance save as it means faith in the potentialities of human nature as that nature is exhibited in every human being irrespective of race, color, sex, birth and family, of material or cultural wealth. This faith may be enacted in statutes, but it is only on paper unless it 
is put in force in the attitudes which human beings display to one another in all the incidents and relations of daily life. ${ }^{29}$

By prioritizing the future development of everyone's potential-especially in the capacities for education, social intelligence, and public deliberation ${ }^{30}$ - Dewey hopes to resolve the tension between what is good for the individual and what is good for the community. This tension naturally arises between what is good for the community now, and what may become good for an individual in the future (the community is no longer a good environment for that person). This tension also naturally arises between what is good for the individual now, and what may become good for an community in the future (a person is no longer a good fit with that community). The Platonic solution is to ascertain and fix, once and for all, the capacities of the individual and the needs of the community to ensure adequate conformity forever. The Deweyan solution takes the exact opposite course: neither the capacities of the individual nor the needs of the community are known fixed matters, but these instead require endless readjustment to each other as they ceaselessly evolve. This social evolution has no telos-no guaranteed direction or eventual harmony-and Dewey's political theory has no need to idealistically postulate such things, just as biological evolution has eliminated reference to any ideal direction or final harmony.

Dewey does postulate continual social conflict and competition. What may be a necessary and tragic conflict between the good of the individual and the good of the community, if either is given a fixed conception, is profoundly transformed by the Deweyan notion of potentiality. There will always be conflicts of many sorts within communities; but no tragic and unalterable antagonism is destined to forever impoverish either the individual or the community's good. Furthermore, the social conflicts that do constantly arise can be, with serious effort, successfully mediated and occasionally resolved before erupting into armed warfare, if participants are in part motivated by concern and respect for others.

Dewey's preferred form of democracy, what has been here termed "public deliberation polyarchy," describes how social conflicts can be managed by citizens for maintaining the Moral Community—what Dewey called the Great Community in The Public and Its Problems. A democracy's citizens, educated in the civic tools of social intelligence and motivated by the benefits of cooperation to respect each other, can be effective at managing their social conflicts. Furthermore, all people have an ethical right to the equal opportunity to become as valuable to the community as they can become. Dewey concluded that only democracy can ensure each person's right to participate in social inquiry for community benefit.

\section{NOTES}

1. Attention to Dewey's political philosophy has never been greater, evidenced by a proliferation of books about Dewey since 1985 and the numerous articles in philosophical, political science, and legal journals every year. During Dewey's lifetime, little academic 
scrutiny was given to his political writings, as documented by James Farr, "John Dewey and American Political Science” American Journal of Political Science 43 (April 1999), 520-41. Plenty of pragmatists were still to be found, to be sure, across the social sciences; the "eclipse of pragmatism" after Dewey's death occurred only in philosophy departments. The most effective philosophers responding to critics of democracy, who were still proliferating into the 1970s, came from defenders of Kantian and Lockean traditions, such as John Rawls and Robert Nozick. It was only in the aftermath of that debate, centered mostly on the nature and justification of rights, that some revivers of republican, communitarian, and deliberative models of democracy began to recall Dewey as a leading defender of liberal participatory democracy. Another significant recollection arose from Richard Rorty's repeated appreciation for Dewey in such writings as "Pragmatism, Relativism and Irrationalism," Proceedings of the American Philosophical Association 53 (August 1980), 719-38; and "Postmodernist Bourgeois Liberalism." Journal of Philosophy 80 (October 1983), 583-89. Rorty's sudden impact on political and legal theory in the 1980s and early 1990s is detailed in William G. Weaver, "Richard Rorty and the Radical Left," Virginia Law Review 78 (April 1992), pp. 729-57. More recently, Jürgen Habermas has also recognized Dewey; see Between Facts and Norms, trans. William Rehg (Cambridge, MA: MIT Press, 1998), 110 and 304.

2. For Rorty, Dewey offers a post-metaphysical vision of politics as endless conversation without appeal to "truth" or any principles of justice or morality. Some have rightly protested that Rorty ignores Dewey's pragmatic justifications for applying scientific inquiry to morality and politics. See, for example, Richard Bernstein, "One Step Forward, Two Steps Backward: Richard Rorty on Liberal Democracy and Philosophy," Political Theory 15 (November 1987), 538-63, and Robert Westbrook, Democratic Hope: Pragmatism and the Politics of Truth (Ithaca, NY: Cornell University Press, 2005), chap. 7. Alan Ryan depicts Dewey's political aspirations as the establishment of a "planning society" to steer between free-market capitalism and communism, in John Dewey and the High Tide of American Liberalism (New York: W. W. Norton, 1995), chap. 8. Westbrook finds faith in the Great Community lying behind and morally guiding the deliberative process of citizen planning, in John Dewey and American Democracy (Ithaca, NY: Cornell University Press, 1995), chap. 9. Like Westbrook, J. T. Kloppenberg perceives how Dewey's lingering Hegelianism protests the artificial liberalism of excessive individuality and instead emphasizes social connectedness; see Uncertain Victory: Social Democracy and Progressivism in European and American Thought, 1870-1920 (New York: Oxford University Press, 1986). Only a handful of Dewey commentators go further, perceiving that the vocation of citizenship is ultimately moral and humanitarian. Jeffrey Stout admires a Dewey who defends democracy as a moral tradition in Democracy and Tradition (Princeton, NJ: Princeton University Press, 2004). Melvin Rogers also finds the quest for ethical life within Dewey's democratic society in The Undiscovered Dewey: Religion, Morality, and the Ethos of Democracy (New York: Columbia University Press, 2009). William Caspary's Dewey on Democracy (Ithaca, NY: Cornell University Press, 2000) traces Dewey's politics to an ethical demand for peaceful conflict resolution; while Judith Green's Deep Democracy: Community, Diversity, and Transformation (Lanham, MD: Rowman and Littlefield, 1999) grounds Dewey's politics in the ethical quest for pluralism. An outstanding defense of Dewey's theory of deliberative and participatory democracy is by Axel Honneth, "Democracy as Reflexive Cooperation: John Dewey and the Theory of Democracy Today," Political Theory 26 (1998), 763-83.

3. $L W$ 2: 304-305. References to the critical edition of Dewey's works, edited by Jo Ann Boydston and published by Southern Illinois University Press, 1967-1990, are indicated by 
EW (Early Works of John Dewey), MW (Middle Works of John Dewey), or LW (Later Works of John Dewey) followed by volume and page numbers.
4. $L W 2: 306$.
5. $L W 2: 326$.
6. $L W 13: 151$.
7. MW 5: 394-95.

8. $L W 6: 188$.

9. All the same, a minimum set of rights might be defended as pragmatically justifiable for all communities that deserve the name. Dewey, as will be seen below, can be interpreted as undertaking this sort of defense. See also Beth J. Singer, Pragmatism, Rights, and Democracy (New York: Fordham University Press, 1999).

10. $L W 2: 329$.

11. $L W 11: 375$.

12. $L W 11: 221$.

13. $L W 7: 359$.

14. As the epistemic justification is the most common interpretation of Dewey's political theory, only a small sample of scholars in this category can be mentioned here. They all agree that Dewey held that democracy's primary function is to supply a public forum for citizens to intelligently and fairly deliberate about their social problems. Sidney Hook's writings are exemplary of this approach to Dewey's political theory; see Sidney Hook on Pragmatism, Democracy, and Freedom, ed. Robert Talisse and Robert Tempio (Amherst, NY: Prometheus Books, 2002). Hilary Putnam similarly draws attention to this epistemological justification in "A Reconsideration of Deweyan Democracy in Renewing Philosophy (Cambridge, MA: Harvard University Press, 1992), 180-200. Some scholars, like Alan Ryan in John Dewey and the High Tide of American Liberalism and Terry Hoy in The Political Philosophy of John Dewey (Westport, CT: Greenwood, 1998), fasten Dewey's politics to his concern for citizen fulfillment in the face of the alienating forces of industrial capitalism. A separate and smaller group of scholars in this epistemic category likewise focus on citizen fulfillment but do not fail to note that Dewey was also concerned for the fulfillment of all persons in the community. See for example Matthew Festenstein, Pragmatism and Political Theory: From Dewey to Rorty (Chicago: Chicago University Press, 1997). David Fott likewise recognizes the ideal of harmonizing the individual with the community in Dewey's democratic theory. However, Fott is not as optimistic as Dewey about justifying this ideal. See Fott, John Dewey: America's Philosopher of Democracy (Lanham, MD: Rowman and Littlefield, 1998). Eric MacGilvary also discerns principled moral commitments at the heart of Dewey's pragmatic theory of democracy, but MacGilvary worries that these moral commitments are obstacles to genuine pluralism and liberalism. See MacGilvary, Reconstructing Public Reason (Cambridge, MA: Harvard University Press, 2004), chap. 5.

15. $L W$ 11: 56.

16. The Public and Its Problems (1927), LW 2: 365.

17. Dewey took close notice of Walter Lippmann's scathing critiques of progressive democracy in Public Opinion (1921) and The Phantom Public (1925). Dewey's own The Public and Its Problems (1927) was primarily a response to Lippmann's alarmist charges against the dangers of excessive public participation in politics.

18. $L W 14: 226-27$.

19. Dewey's public deliberation polyarchy, by emphasizing the dominant role for selfforming voluntary publics, is only distantly related to Joshua Cohen and Charles Sabel's proposal for "Directly-Deliberative Polyarchy," European Law Journal 3 (1997), 313-42. Much 


\section{JOHN SHOOK}

closer to Dewey is Michael C. Dorf and Charles F. Sabel, "A Constitution of Democratic Experimentalism," Columbia Law Review 98 (1998), 267-473, who acknowledge Dewey as an important source for their model of incremental and experimental politics. Very few scholars have recognized Dewey's view of publics as credible or significant to deliberative democracy. More common is Eric MacGilvray's view that Dewey's political philosophy is really far more dependent on the Public's unifying conception of its general interests rather than the pluralistic arena of competing publics. See Reconstructing Public Reason, p. 142.

20. $L W 7: 348-49$.

21. Among recent work elaborating a modern republicanism, Philip Pettit's writings have much in common with Dewey's social and political theory; see Pettit, Republicanism: A Theory of Freedom and Government (Oxford: Oxford University Press, 1997).

22. $L W$ 11: 48.

23. $L W 14: 226-27$.

24. $L W$ 11: 187.

25. $L W$ 13: 154-55.

26. $L W 7: 350$.

27. The Public and Its Problems (1927), LW 2: 328.

28. $L W$ 14: 228.

29. $L W$ 14: 226.

30. See the author's essay “Dewey's Vision of Equal Opportunity for Education in a Democracy," in Pragmatism and the Problem of Race, eds. William Lawson and Donald Koch (Bloomington, IN: Indiana University Press, 2004), pp. 48-72.

John Shook is a research associate in Philosophy and a faculty member of the Science and the Public EdM program at the University at Buffalo, New York. E-mail: jshook@pragmatism.org. 